\begin{tabular}{c} 
Volume and Issues Obtainable at Center for Sustainability Research and Consultancy \\
Review of Politics and Public Policy in Emerging Economies \\
ISSN: 2708-3829 (E): 2708-356X \\
Volume 1: No. 2, December 2019 \\
CSRᄃ \\
Journal homepage: www.publishing.globalcsrc.org/rope \\
\hline
\end{tabular}

\title{
Impact of Climate Change on the Number of Threatened Species: International Evidence
}

\author{
${ }^{1}$ Muzafar Shah Habibullah , ${ }^{2}$ Badariah Haji Din, ${ }^{3}$ Siow-Hooi Tan \\ ${ }^{1}$ Putra Business School, Malaysia: muzafar@putrabs.edu.my \\ ${ }^{2}$ College of Law Government and International Studies, Universiti Utara Malaysia, Malaysia. \\ ${ }^{3}$ Faculty of Management, Multimedia University, Malaysia
}

\begin{tabular}{l} 
ARTICLE DETAILS \\
\hline History \\
Revised format: November 2019 \\
Available Online: December 2019
\end{tabular}

\section{Keywords}

Climate Change, Biodiversity

Loss, Threatened Species,

Governance, International

Evidence

\section{JEL Classification:}

Q54, G34, G39

\begin{abstract}
Global warming is the price for economic development. Rapid industrialization produces greenhouse gases that trap the heat and make the earth warmer. The rise in temperature and changes in precipitation resulted in extreme weather conditions. Global climate change affects both physical and biological environments and the impacts on biodiversity is directly and indirectly. The direct effects of climate change includes the increased in temperature and precipitation that affect individual organisms, populations, species distribution and ecosystem compositions and functions. The indirect effects of climate change are through increased salinity and extreme weather events such as floods, cyclones and droughts that will have a profound negative impacts on the forest and biodiversity. The present study investigates the impact of climate change on the number of threatened species as proxy for biodiversity loss using a cross-national data consisting of 98 countries. We have estimated the impact of temperature, precipitation and the number of natural disasters occurrences on the number of threatened species, in particular birds, fishes, mammals, plants and reptiles. As control variables, we have considered government effectiveness (proxy for good governance) and the level of economic development (proxy for wealth). By employing Ordinary Least Square (OLS) with robust standard error and quantile regressions analyses, our results suggest that all three climate change indicators - temperature, precipitation and the number of natural disasters occurrences increase the number of threatened species (biodiversity loss). Higher economic development also affect the number of threatened species positively. On the other hand, good governance such as government effectiveness reduces the number of threatened species. Thus, practicing good governance, promoting conservation of the environment and the control of greenhouse gasses would able to mitigate biodiversity loss.
\end{abstract}

(C) 2019 The authors, under a Creative Commons AttributionNonCommercial 4.0

Corresponding author's email address: muzafar@putrabs.edu.my

Recommended citation: Habibullah, M. S., Din, B. H. \& Tan, S. H., (2019). Impact of Climate Change on the Number of Threatened Species: International Evidence. Review of Politics and Public Policy in Emerging Economies, 1(2), 61-78

DOI: $10.26710 /$ rope.v1i2.1134 


\section{Introduction}

The importance of biodiversity has caught the world's attention. In 1992, the leaders of 150 countries signed the Convention on Biological Diversity (CBD) during the Rio Earth Summit, with the commitment to the conservation of biodiversity, sustainable use of biological resources and equitable sharing of the advantages arising from the use of biodiversity benefits (Earthwatch Institute, 2002). However, for almost 3 decades this effort has not been a success. The World Wildlife Fund (2016) portrays an alarming picture of the global biodiversity. The Living Planet Index which measures biodiversity abundance levels shows a persistent downward trend in which the species population abundance declined by 58\% between 1970 and 2012; and by 2020 the species population is forecasted to decline by $67 \%$. Figure 1 presents an increasing trend in the numbers of threatened species worldwide. The number of threatened species - plants, fishes, amphibians, mollusks, birds, mammals, insects and reptiles have shown an increasing trends for the last two decades. For example, for the 10 years period from 2006 to 2015, fishes, mollusks and reptiles experienced biodiversity loss, on average, at the rate of $8.0 \%, 8.5 \%$ and $12.5 \%$, respectively. According to WWF (2016), the decline in species is due to a variety of factors including unsustainable agriculture, fisheries, mining, habitat loss and degradation, overexploitation, climate change and pollution. On the other hand, Millennium Ecosystem Assessment (2005) reports that $60 \%$ of the ecosystem has been degraded or used unsustainably. It was found that the world's ecosystem changed more rapidly in the second half of the twentieth century than at any time in human history. Over the past few hundred years, humans have increased the species extinction rate by as much as 1,000 times over the planet's history.

Studies have reiterated that one of the most important driver of the current loss of biodiversity is climate change (MEA, 2005; Brook et al., 2008; Guo et al., 2017). Climate change has both direct and indirect effects on the ecosystem. Direct effects include those arising from increased temperature and increased $\mathrm{CO}_{2}$ levels associated with global climate change. These direct effects give rise to several potentially major indirect effects such changes in hydrologic cycles (precipitation and evaporation) and an increasing magnitude and frequency of extreme weather such as floods, cyclones and droughts that will have a profound negative impact on biodiversity (Adler et al., 2009; Rinawati et al., 2013). Tol (2009) claims that climate change is the mother of all externalities and have a profound impact on biodiversity not only through changes in temperature and precipitation, but also the ways climate change might affect ocean acidification, land use and nutrients, and also the proliferation of invasive alien species into new habitats. On the other hand, Thomas et al. (2004) point out that climate change could result in the extinction of more than a million terrestrial species in the next 50 years.

The purpose of the present study is to empirically investigate the effects of climate change on the number of threatened species - birds, fishes, mammals, plants and reptiles using cross-national data consisting of 98 countries. In this study, the number of threatened species were used as a proxy for biodiversity loss. The CBD defines biodiversity loss as the loss of the components of biodiversity that includes biomes, habitats and ecosystem, species and populations and genetic diversity (CBD COP 7 Decision VII/30). In other words, biodiversity loss is a reduction in the variety of life on Earth (Bernstein, 2017). To proxy for the climate change variables, we have included the number of natural disasters occurrences, temperature, and precipitation. As control variables we have included real Gross Domestic Product (GDP) (proxy for the level of economic development), and government effectiveness (proxy for good governance).

The paper is organized as follows. In the next session we discuss the literature that relates biodiversity with climate change; and in section 3 we present the methods of estimation used in the analysis. Section 4 presents the results, while the last section contains our conclusion.

\section{Literature Review}

Climate change is the term used to describe a gradual increase in the average temperature of the Earth's atmosphere and its ocean. Due to global warming the species that live in the forest will be affected, both by changing habitat and in direct response to temperature increases and changes in precipitation and 
extreme weather events (Sarkar, 2012). During the 1990s climate change emerges as one of the potential threats to biodiversity (UNEP, 2002). Furthermore, climate change could lead to severe adverse impacts on the ecosystems and on the goods and services they provide (IPCC, 2001). Climate change is an umbrella crisis in that it has social, economic, political and ecological impacts, including biodiversity loss (Rosales, 2008). Evidences have shown that climate change can affect biodiversity among other things, by changing life cycles, developing new physical traits, by shifting habitat ranges and species distribution, changes in abundance, changes in migration patterns, and changes in the frequency and severity of pest and disease outbreaks (Reed, 2012; Hui, 2013; Sintayehu, 2018).

Empirical studies that have been conducted to investigate the impact of climate change on the loss of biodiversity is rather lacking. For example, earlier work by Asafu-Adjaye (2003) by using dummy variable to account for climatic effects on biodiversity; and his study found that climate change has positive impact of the number of threatened mammals, birds and plants. Similar work by Shandra et al. (2010) by using dummy variable to measure climate change, however, found that tropical climate has no effects on the number of threatened species - mammals, and birds; but when using forest loss as proxy for biodiversity loss, Shandra et al. (2011) found evidence that tropical climate affect forest loss or deforestation. On the other hand, Gren et al. (2016) investigate the effects of climate change on biodiversity loss at the global scale by using both temperature and precipitation to proxy for the direct effects of climate change. The direct effects of climate change such as the increased in temperature and precipitation affect individual organisms, populations, species distribution and ecosystem compositions and functions (UNU-IAS, 2010; Reed, 2012). Similarly, Amano et al. (2018) also include both temperature and precipitation in their study on global waterbird populations. Findings from both studies show positive relationships between biodiversity loss and both temperature and precipitation. The increase in temperature and precipitation increases the loss of biodiversity.

Nevertheless, the indirect effects of climate change through extreme weather events such as floods, cyclones and droughts also have a profound negative impacts on biodiversity. Thus, the occurrences of natural disaster would have a positive impact on biodiversity loss. Natural disasters could be the results of earthquakes, extreme temperature, volcanic eruptions, landslides, storms, wildfire, flood and drought. A country that frequently experiences one or more of these catastrophic events will have a devastating impact on biodiversity. Studies by Miura and Kanaya (2017), Porwal et al. (2012) and Fattorini et al. (2018) on earthquake, Bixby et al. (2015) on wild fire, Milner et al. (2013) on flood, Kwit et al. (2000) on hurricane, Fraver (2017) on tornado, Darnaedi and Zulkarnaen (2017) and Lallement et al. (2015) on volcanic eruptions clearly indicate the devastating impact of these natural events on the ecosystem, habitat and biotic. For example, the 2011 Japan earthquake resulted in the disappearance of vegetation and altered habitat structure through changes in topography, bottom elevation and sediment characteristics which induced drastic changes in associated biotic communities (Kanaya et al., 2017; Miura and Kanaya, 2017). Natural disasters such as earthquakes, landslides, floods, droughts, forest fires, extreme low temperature and freezing rain have led to the destruction of many species in China (Guan, 2017). In Indonesia, Darnaedi and Zulkarnean (2017) report that the Krakatau volcanic eruptions has affected biodiversity of the islands around Krakatau, the western part of Java, and the southeastern part of Sumatra. On the other hand, in India, the December 2004 tsunami has impacted the archipelago of Andaman and Nicobar Islands. The island suffered great loss of forest and coastal biodiversity, in which the mangroves, littoral forest, beach forest and low land swamps were most affected (Porwal et al., 2012).

\section{Methodology}

To empirically estimate the impact of climate change on the number of threatened species (or biodiversity loss), we follow the work of others (Asafu-Adjaye, 2003; Shandra et al., 2010; Gren et al. 2016) by specifying the following augmented threatened species-climate change equation, 


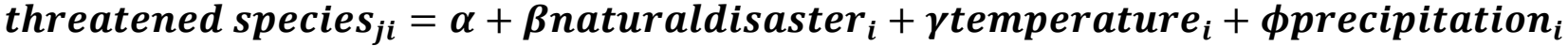 + SrealGDP $_{i}+$ ogovernment effectiveness $s_{i}+\epsilon_{j i}$

where the parameters $\alpha, \beta, \gamma, \phi, \delta$, and $\theta$ are to be estimated and $\epsilon_{j i}$ indicate the error term. The error term is assume to well behave with mean zero and constant variance. It is a priori that we expect $\beta, \gamma, \phi$ and $\delta>0$, and $\theta<0$. Thus, there is a positive relationship between climate change with $j=$ naturaldisaster, temperature, precipitation, and the number of threatened species; in which increase in the frequency of natural disaster events, temperature and precipitation will lead to an increase in the loss of biodiversity (increase in the number of threatened species); and on the other hand, the control variables such as economic development (realGDP) will affect biodiversity loss positively; while improvement in government effectiveness will reduce biodiversity loss. In this study, we employ cross-sectional data analysis for 98 countries. The list of countries included in the study are presented in Table 1.

For the dependent variable, we follow the work of Naidoo and Adamowicz (2001), Asafu-Adjaye (2003), Hoffmann (2004), Shandra et al. (2010) and Halkos (2011) by using the number of threatened species at the country level as proxy for biodiversity loss. In this study we employed the critically endangered, endangered and vulnerable categories of birds, fishes, mammals, plants and reptiles species. This classification were given by the International Union for the Conservation of Nature and Natural Resources (IUCN) Red List of Threatened Animals. According to Hoffmann (2004), the Red List is a comprehensive listing of threatened and endangered species in most nations, and the most widely used source on threatened and endangered species. Figure 2 clearly demonstrates the positive correlation between the total number of threatened species (summed of all five species) and climate change indicators, namely; the occurrences of natural disasters, temperature, and precipitation. The scatter plot clearly demonstrates a positive correlation between the number of threatened species and all three climate change indicators.

As for the control variable, we use real GDP to proxy for the wealth of a nation or the level of economic development. For a country to strive for higher level of economic development, it requires that higher level of economic output to be produced. It is predicted that higher GDP may stimulate demand for agricultural and forest derived product and that causes deforestation, thus, increase the number of threatened species (Asafu-Adjaye, 2003; Culas, 2007). Furthermore, Rosales (2008) asserts that "economic growth is a prime catalyst of biodiversity loss because people desire economic growth for dissimilar reasons - some for the increased accumulation of wealth, others for basic needs". Rosales further notes that because economic growth is the increase of production and consumption of goods and services, and these goods and services derives from the ecosystem that we lives, thus the impact of economic growth on the natural world increases with the size of the economy; and achieving higher economic growth comes with a price. For example, in the United States, a dollar's worth of goods or services produced, on average, $0.36 \mathrm{~kg}$ of $\mathrm{CO}_{2}$ goes into the atmosphere (Suh, 2006). Thus, economic growth is said to be the main driver in increased GHG emissions.

On the other hand, several reports have pointed to weak governance as key driver of biodiversity loss. Swiderska et al. (2008) point out that the ineffectiveness of the international biodiversity governance framework was one of the most significant obstacles to achieving the 2010 target. As a result of poor governance - government with weak law enforcement, lack of transparency that goes in hand with corruption, lack of accountability (in both government and private institutions), failure to engage the indigenous communities are key drivers that led to both ecosystem and biodiversity degradation. On a similar note, the Millennium Ecosystem Assessment (2005) indicates that the degradation of the ecosystem was the result of inappropriate institutional and governance arrangements, corruption and weak regulation and accountability. On the other hand, despite recognizing that the governance of biodiversity is a complex issue, BIO Intelligence Service (2011: pp.29) emphasizes that "good governance processes 
rely on efficient governance that make the best available resources, by engaging all those with a role in implementation and enhancing coherence across governmental interventions and policies. Information should be timely provided to the different stakeholders, and transparency is critical to ensure accountability and responsibility in the decision processes." Nevertheless, despite the growing awareness of conserving biodiversity and the environment; biodiversity and environment are often low on the political agendas where the emphasis on trade and development are often conflict with biodiversity goals. As a result, biodiversity and environment departments that are often weak and due to lack of resources are helpless to engage against the powerful politicians and the business peoples who control the bulk of the investment (Swiderska et al., 2008; BIO Intelligence Service, 2011). In this study we used government effectiveness an indicator of good governance. According to Kaufman et al. (2008), "government effectiveness" measures perceptions of the quality of public services, the quality of the civil service and the degree of its independence from political pressures, the quality of policy formulation and implementation, and the credibility of the government's commitment to such policies (see info.worldbank.org/governance/wgi/index.asp). It is expected that effective government enforcement and policies would mitigate biodiversity loss.

\section{The Empirical Results}

In this study, we have compiled a cross-national data on 98 countries for the year 2011 for the analysis. Data for the number of threatened species were compiled from The Red List published by IUCN. Data for the number of natural disasters occurrences was compiled from the Office of Foreign Disaster Assistance (OFDA)/Centre for Research on the Epidemiology of Disaster (CRED); while data on temperature was taken from Food and Agriculture Organizations (FAO) of the United Nations database which is available at www/fao.org/statistics/database/. The data on precipitation and real GDP were compiled from the World Bank database available online. It is accessible at https://data.worldbank.org/indicator. Data on the government effectiveness was taken from the Worldwide Governance Indicators published by the World Bank (available at http://info.worldbank.org/governance/wgi/index.asp). All variables, except for the number of natural disasters occurrences were transformed into natural logarithm for analysis.

The results of our analysis are presented in Panel A in Table 2. In Table 2 we have estimated six regression equations - birds, fishes, mammals, plants, reptiles and total threatened species (summed of all five species) presented in columns 2 to 7 , respectively. Our results suggest that the adjusted $\mathrm{R}^{2}$ show that the goodness of fit is satisfactory for a cross-sectional data analysis for all the estimated models. Despite similar work on cross-national data analysis, however, unlike the works of Benhin and Barbier (2004), Shandra (2007), McKinney et al. (2009), and Shandra et al. (2011, 2016) which have used Ordinary Least Squares (OLS) to estimate Equation (1) above, instead in this study we follow Asafu-Adjaye (2003) and Barrett et al. (2005) by employing OLS with robust standard errors, to correct for heteroskedasticity that may presence in the data. In fact, the Breusch-Pagan-Godfrey (BPG) test indicates that the null hypothesis of homoscedastic cannot be rejected in the OLS estimations except for fishes. To circumvent the problem of heteroscasticity, we have estimated Equation (1) by using OLS with White's autocorrelationheteroskedasticity-consistent standard errors estimator (Newey and West, 1987).

Generally, our estimated regression equations suggest that climate change play an important role in contributing to the loss of biodiversity. All three climate change indicators - frequency of natural disasters occurrences, temperature and precipitation are statistically significant at least at the 5\% significance level (except for natural disasters on plants, and precipitation on fishes, mammals and reptiles). For example, for the bird species, a $10 \%$ increase in the number of frequency in natural disasters events, calculated at their mean 2.826531, increases the number of threatened bird species by $1.5 \%$. Among the three climate change measures, it seems that temperature has a greater impact on biodiversity loss, followed by precipitation and natural disasters. For example, a 10\% increase in temperature, on average, increases the number of threatened bird species by $10.7 \%$ compared to a $2 \%$ increase in the number of threatened bird species as a result of the $10 \%$ increase in precipitation. This results are consistent with the rest of the threatened species. Generally, our results are similar to the work done by Gren et al. (2016) in which they 
also found that the impact of temperature is much greater than the impact of precipitation on biodiversity loss using global data. On the contrary, the study by Amano et al. (2018) on waterbird populations found that the impact of precipitation is much larger than the impact of temperature. Nevertheless, our study seem to suggest that the impacts of temperature and precipitation are more destructive on biodiversity loss compare to the occurrences of natural disaster events.

On the other hand, variable real GDP which proxy for the level of economic development clearly suggest that, on average, an increase in economic prosperity does contribute to biodiversity loss. The effects of real GDP on biodiversity loss is positive and statistically significant at $1 \%$ level in all six estimated equations. In other words, achieving higher economic growth is at the expense of biodiversity. Higher economic growth drives for further economic development, urbanization, energy consumption and $\mathrm{CO}_{2}$ emissions. Similar findings were also found by Barrett et al. (2005), Shandra et al. (2016), Clausen and York (2008), Naidoo and Adamowicz (2000), McKinney et al. (2009), Gren et al. (2016) and Rosales (2008).

Lastly, our estimated regressions suggest that the relationships between good governance and biodiversity loss is negative, and significant in all estimated equations except for fishes and reptiles. In other words, on average, our results suggest that the improvement in governance through effective government practices and better enforcement of policies mitigate biodiversity loss. Our results support the earlier works by Umemiya et al. (2010), Smith et al. (2003), Culas (2007), Amano et al. (2018) and Baynham-Herd et al. (2018). The studies by Amano et al. (2018) and Baynham-Herd et al. (2018) suggest that biodiversity conservation responses positive to good governance. On average, a $10 \%$ increase in government effectiveness, the number of threatened species or biodiversity loss reduces by $4.8 \%$ for birds, $5.8 \%$ for mammals, $7.8 \%$ for plants, and $4.2 \%$ for total species.

\section{Further Analysis Using Quantile Regression}

It is well known that OLS estimates the effect of the explanatory variables on the mean of the conditional distribution of the dependent variable. To allow the effect of the explanatory variables on the entire conditional distribution of the dependent variable, we employ the quantile regression introduce by Koenker and Basset (1978). Quantile regression allows the estimated parameters to differ at different points of the conditional distribution of the dependent variable. Therefore, a number of different quantile regressions give us a more complete description of the underlying conditional distribution. Another advantage of using quantile regression is that it is robust to the problem of heteroscedasticity and outliers. Koenker (2005), Koenker and Basset (1978), and John (2015) reiterate that the quantile regression inherits its robustness property from median regression that can produce good and reliable estimates even in the presence of extreme outliers. As shown in Panel B in Table 2, the DFITS test clearly suggest that outlier is an issue. Five to seven countries have been identified as potential outliers that can influence the parameter estimates.

Following the work by Halkos (2011), Habibullah et al. $(2015,2016)$ and Habibullah et al. (2018), the quantile regression is defined as follows

$$
\begin{aligned}
& \text { threatened species }_{i}=x_{i}^{\prime} \beta_{\tau}+\mu_{\tau i} \\
& \text { Quantile }_{\tau}\left(\text { threatened species } s_{i} \mid x_{i}\right)=x_{i}^{\prime} \beta_{\tau}
\end{aligned}
$$

where $x_{i}^{\prime}$ equals a vector of explanatory variables as defined above, $\beta_{\tau}$ equals the vector of parameters associated with the $\tau$-th percentile, and $\mu_{\tau i}$ equals an unknown error term. The Quantile $_{\tau}$ (threatened species $\left.x_{i} \mid x_{i}\right)=x_{i}^{\prime} \beta_{\tau}$ equals the $\tau$-th conditional quantile of threatened species given $x$ with $\tau \in(0,1)$. By estimating $\beta_{\tau}$, using different values of $\tau$, quantile regression permits different parameters across different quantiles of threatened species. In other words, repeating the estimation for 
different values of $\tau$ between 0 and 1, we trace the distribution of threatened species conditional on $x$ and generate a much more complete picture of how explanatory variables affect the dependent variable. The $\tau$-th quantile regression estimates $\beta_{\tau}$, by solving the following minimization problem and the median regression occurs when $\tau=0.5$ and the coefficients of the absolute values both equal one,

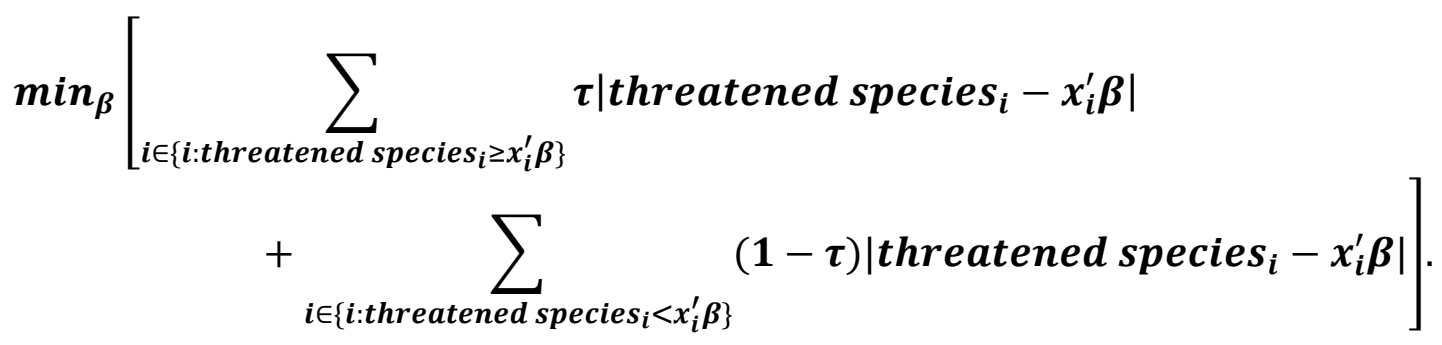

The results of the quantile regression estimates are presented in Table 3, in Panels A to F for birds, fishes, mammals, plants, reptiles and total species, respectively. The quantile estimates reveal several interesting results as compared to the mean regression as presented in Table 2. First, in our mean regression, the occurrences of natural disaster play an important role affecting biodiversity in all sample countries, except for threatened plant species. However, our quantile regression results suggest that natural disaster events affect the number of threatened species in countries at the lower quantiles $-10^{\text {th }}, 20^{\text {th }}, 30^{\text {th }}$ and $40^{\text {th }}$ quantiles for birds; $10^{\text {th }}$ and $20^{\text {th }}$ quantiles for fishes and plants; $10^{\text {th }}$ quantile for mammals; and $10^{\text {th }}, 20^{\text {th }}$ and $30^{\text {th }}$ quantiles for reptiles. This results is revealing because natural disaster events show no impact in our mean regression, but our quantile regression show otherwise, that is the occurrences of natural disaster impacted countries with small number of threatened plant species. If smaller number of threatened species is associated with low income countries (see Figure 3), we can make conjecture that biodiversity in less developing countries are more susceptible and vulnerable to the occurrences of natural disaster events; but for the higher income countries with greater number of threatened species, biodiversity is not affected by the events of natural disasters.

Second, the effects of temperature from our quantile regression estimates suggest that temperature has global impact on biodiversity loss. Generally, temperature is statistically significant at least at the 5\% level for all threatened species, at all quantiles $-10^{\text {th }}, 20^{\text {th }}, 30^{\text {th }}, 40^{\text {th }}, 50^{\text {th }}, 60^{\text {th }}, 70^{\text {th }}, 80^{\text {th }}$ and $90^{\text {th }}$ quantiles (except for birds at $90^{\text {th }}$ quantile, and fishes at $60^{\text {th }}$ and $90^{\text {th }}$; mammals at $10^{\text {th }}, 20^{\text {th }}, 30^{\text {th }}, 70^{\text {th }}, 80^{\text {th }}$ and $90^{\text {th }}$ quantiles;plants at $10^{\text {th }}$ and $20^{\text {th }}$ quantiles; and reptiles at $10^{\text {th }}$ quantiles). This result implies that both countries (low income) with smaller number of threatened species, and countries with large number of threatened species (high income) are affected by rising temperature. Third, our quantile regression results for precipitation indicate that precipitation has damaging impact on selected threatened species. However, at the 5\% level of significant, precipitation has no impact on threatened fish and reptile species. Nevertheless, precipitation show significant effects on birds (at $40^{\text {th }}, 50^{\text {th }}, 60^{\text {th }}, 70^{\text {th }}, 80^{\text {th }}$ and $90^{\text {th }}$ ), mammals (at $80^{\text {th }}$ ), and plants at all quantiles. Interestingly, our mean regression results also indicate that precipitation, on average, has no impact on fishes, mammals and reptiles at the $5 \%$ level of significance.

On the other hand, the level of economic development or the wealth for a nation contributes to the increase in the number of threatened species. The real GDP variable is consistently statistically significant at least at the 5\% level for all threatened species. In agreement with Rosales (2008), our results imply that as a nation develop from low income to high income country, the shift of the economy from agriculturebased to the services-based sectors, has not led to an improve in biodiversity loss. Probably, this has led to the failure to reduce the rate of biodiversity loss at the global, regional and national level. The Secretariat of the Convention on Biological Diversity (2010: pp. 17) reports that "Despite an increase in conservation efforts, the state of biodiversity continues to decline, according to most indicators, largely because the pressures on biodiversity continue to increase. There is no indication of a significant reduction in the rate of decline in biodiversity, nor of a significant reduction in pressures upon it." Nevertheless, without the political will from the government on addressing the conservation effort to reduce the rate of biodiversity 
loss, whatever plans and policies put in place will not succeed. In fact, our government effectiveness variable suggests that the effectiveness of the government in formulating and implementing policies and their enforcement can mitigate biodiversity loss. Generally, our results indicate that, the number of threatened birds, mammals, plants, and total species can be reduce with effective government efforts in terms of plans, policies and enforcements. Our quantile regression estimates for fishes and reptiles give similar results with our mean regression estimates where government effectiveness has no impact on the number of threatened fish and reptile species.

Lastly, the last column in Table 3 shows the results of aggregated number of threatened species by summing all five threatened species - birds, fishes, mammals, plants and reptiles. The result is intriguing. The quantile regression estimates suggest that temperature, precipitation and the level of economic development affected the total number of threatened species for all countries, and for all small and large number of total threatened species. On the other hand, the number of occurrences of natural disaster events affected low income countries with small number of total threatened species; while in higher income countries with large number of total threatened species the effectiveness of government policies able to mitigate biodiversity loss.

\section{Conclusion}

In this study we have empirically estimated the impact of climate change on biodiversity loss using the number of threatened species as proxy. Using a cross-national sample of 98 countries, we able to determine that climate change - the occurrences of natural disaster events, temperature and precipitation, play an important role in affecting biodiversity loss. Generally, our mean regression results suggest that the impact on biodiversity loss are more affected by the changes in temperature and precipitation than the changes in the frequency of the natural disaster events. Nevertheless, all this effects point to the global warming which was the result when nations strive for higher economic growth. In this sense, Rosales (2008) was right to infer that "economic growth is the main driver of climate change-related biodiversity loss". We also found that the level of economic development contribute in the loss of biodiversity. On the other hand, good governance - government effectiveness in formulating, implementing and enforcing plans and policies able to mitigate biodiversity loss.

In this study, we have also estimated quantile regression for our further analysis. The quantile regression estimates reveal that countries with smaller number of threatened species are more susceptible and vulnerable to the events of natural disaster. The effects of rising temperature on biodiversity loss is a global phenomenon whereby both low income countries with smaller number of threatened species and high income countries with large number of threatened species are affected. However, the impact of precipitation on biodiversity loss is more selective. Increase in precipitation only affects threatened bird and plant species, but not fishes, mammals and reptiles. On the other hand, the level of economic development play an important role in increasing biodiversity loss. Countries with smaller number of threatened species as well as countries with larger number of threatened species have to pay the price for economic development. Inevitably, biodiversity loss is a consequent of economic development. Further, our quantile regression results suggest that "government effectiveness" has an important role to play in mitigating biodiversity loss, in particular for conserving the number of birds, mammals and plants species. Lastly, by disaggregating the data on the number of threatened species gives a different scenario when compared to aggregated data on the number of threatened species. Policy implications will have a different impact for this two scenarios.

Thus, for effective biodiversity conservation a nation should use their wealth and effort to reduce the amount of carbon dioxide emissions in order to combat global warming and natural disasters mishaps. The government, and the private sector to be held responsible for the loss in biodiversity. Their activities in achieving the ultimate goal of prosperity and profit, however, at the expense of biodiversity which on the other hand, is very important to support life on earth. Nevertheless, effective government efforts in planning, implementing policies and enforcement of rule of law will help in mitigating the loss of 
biodiversity.

\section{Acknowledgements}

Funding for this project comes from the Fundamental Research Grant Scheme (FRGS/1/2016/SS08/UPM/01/5; Grant No. 05-01-16-1784FR) provided by the Ministry of Higher Education (MOHE) Malaysia.

\section{References}

Adler, P.B., Leiker, J., \& Levine, J.M. (2009). Direct and indirect effects of climate change on a Prairie plant community. PLoS ONE, 4(9), e6887. doi:10.1371/journal.pone.0006887

Amano, T., Szekely, T., Sandel, B., Nagy, S., Mundkur, T., Langendoen, T., Blanco, D., Soykan, C.U., \& Sutherland, W.J. (2018). Successful conservation of global waterbird populations depends on effective governance. Nature, 553, 199-202.

Asafu-Adjaye, J. (2003). Biodiversity loss and economic growth: A cross-country analysis. Contemporary Economic Analysis, 21(2), 173-185.

Barrett, C.B., Gibson, C.C., Hoffman, B., \& McCubbins, M.D. (2006). The complex links between governance and biodiversity. Conservation Biology, 20(5), 1358-1366.

Benhin, J.K.A. \& Barbier, E.B. (2004). Structural adjustment programme, deforestation and biodiversity loss in Ghana. Environmental and Resource Economics, 27, 337-366.

Bernstein, A. (2017). Biodiversity, health implications of. In S.R. Quah (Ed.). International Encyclopedia of Public Health (2nd Edition). USA: Academic Press. pp.219-222.

BIO Intelligence Service. (2013). Comparative analysis of biodiversity governance in Europe. Europe: GIP ATEN.

Bixby, R.J., Cooper, S.D., Gresswell, R.E., Brown, L.E., Dahm, C.N., \& Dwire, K.A. (2015). Fire effects on aquatic ecosystems: An assessment of the current state of the science. Freshwater Science, 34(4), 1340-1350.

Brook, B.W., Sodhi, N.S., \& Bradshaw, C.J.A. (2008). Synergies among extinction drivers under global change. Trends in Ecology \& Evolution, 23, 453-460.

CBD (Convention on Biological Diversity). (2019). COP 7 Decision VII/30. Available at https://www.cbd.int/decision/cop/?id=7767

Clausen, R., \& York, R. (2008). Global biodiversity decline of marine and freshwater fish: A crossnational analysis of economic, demographic and ecological influences. Social Science Research, 37, 1310-1320.

Culas, R.J. (2007). Deforestation and the environmental Kuznets curve: An institutional perspective. Ecological Economics, 61, 429-437.

Darnaedi, D., \& Zulkarnaen, I. (2017). Disasters and biodiversity in the Ring of Fire of the Indonesian archipelago. Biology International, Special Issue 36, 39-46.

Earthwatch Institute. (2002). Business \& Biodiversity: The Handbook for Corporate Action. Switzerland: Earthwatch Institute, IUCN and World Business Council for Sustainable Development.

Fattorini, S., Di Lorenzo, T., \& Galassi, D.M. (2018). Earthquake impacts on microcrustacean communities inhabiting groundwater-fed springs alter species-abundance distribution patterns. Scientific Reports, 8: 1501. Doi: 10.1038/s41598-018-20011-1.

Fraver, S., Dodds, K.J., Kenefic, L.S., Morrill, R., Seymour, R.S., \& Sypitkowski, E. (2017). Forest structure following tornado damage and salvage logging in northern Maine, USA. Canadian Journal of Forestry, 47, 560-564.

Gren, I.M., Campos, M., \& Gustafsson, L. (2016). Economic development, institutions and biodiversity loss at the global scale. Regional Environmental Change, 16, 445-457.

Guan, K. (2017). Disaster and biodiversity in China. Biology International, Special Issue 36, 30-38.

Guo, D., Desmet, P.G., \& Powrie, L.W. (2017). Impact of the future changing climate on the Southern Africa biomes and the importance of geology. Journal of Geoscience and Environment Protection, 5, 1-9.

Habibullah, M.S., Din, B.H., Choo, W.C., \& Radam, A. (2015). Impact of tourism on the number of 
threatened fish species: A cross-country analysis. In A.H. Jantan, S.R. Hussin and M.S.A. Karim (Editors). Trends in Hospitality \& Tourism. Serdang: Universiti Putra Malaysia Press. pp. 92-101.

Habibullah, M.S., Din, B.H., Choo, W.C., \& Radam, A. (2016). A cross-country analysis on the impact of tourism on threatened plant species. Procedia-Social and Behavioral Sciences, 224, 14-19.

Habibullah, M.S., Din, B.H., Choo, W.C., \& Tan, S.H. (2018). The number of tourist arrivals, governance and their impact on threatened bird species: Worldwide evidence. The Journal of Social Sciences Research, Special Issue, 6, 28-36.

Halkos, G.E. (2011). Nonparametric modelling of biodiversity: Determinants of threatened species. Journal of Policy Modeling, 33, 618-635.

Hoffmann, J.P. (2004). Social and environmental influences on endangered species: A cross-national study. Sociological Perspective, 47(1), 79-107.

Hui, D. (2013). Global climate change and biodiversity: Issues and future research. Journal of Biodiversity and Endangered Species, 1: e105. doi: 10.4172/2332-2543. 1000e105

IPCC. (2001). IPCC Third Assessment Report - Climate Change 2001. Working Group II: Impacts, adaptation and vulnerability. Geneva: World Meteorological Organization and United Nations Environment Programme.

John, O.O. (2015). Robustness of quantile regression to outliers. American Journal of Applied Mathematics and Statistics, 3(2), 86-88.

Kanaya, G., Suzuki, T., Kinoshita, K., Matsumasa, M., Yamada, K., Seike, K., Okoshi, K., et al. (2017). Disaster-induced changes in coastal wetlands and soft-bottom habitats: An overview of the impacts of the 2011 tsunami and Great East Japan earthquake. Biology International, Special Issue $36,62-80$.

Kaufman, D., Kraay, A., \& Mastruzzi, M. (2008). Governance Matters VII: Governance Indicators for 1996-2007. World Bank Policy Research June 2008., Washington DC.: The World Bank.

Koenker, R. (2005). Quantile Regression. New York: Cambridge University Press.

Koenker, R. \& Basset, G. (1978). Regression Quantiles. Econometrica, 46, 33-50.

Kwit, C., Platt, W.J., \& Slater, H.H. (2000). Post-hurricane regeneration of pioneer plant species in south Florida subtropical hardwood hammocks. Biotropica, 32(2), 244-251.

Lallement, M., Macchi, P.J., Vigliano, P., Juarez, S., Recheong, M., Baker, M., Bouwes, N., \& Crowl, T. (2016). Rising from the ashes: Changes in salmonid fish assemblages after 30 months of the Puyehue-Cordon Caulle volcanic eruption. Science of the Total Environment, 541, 1041-1051.

McKinney, L.A., Fulkerson, G.M., \& Kick, E.L. (2009). Investigating the correlates of biodiversity loss: A cross-national quantitative analysis of threatened bird species. Human Ecology Review, 16(1), 103-113.

MEA (Millennium Ecosystem Assessment). (2005). Ecosystems and Human Well-being: Synthesis. Washington, D.C.: Island Press.

Milner, A.M., Robertson, A.L., McDermott, M.J., Klaar, M.J., \& Brown, L.E. (2012). Major flood disturbance alters river ecosystem evolution. Nature Climate Change, 3, 137-141.

Miura, O., \& Kanaya, G. (2017). Impact of the 2011 Tohoku earthquake tsunami on marine and coastal organisms. Biology International, Special Issue 36, 81-92.

Naidoo, R., \& Adamowicz, W.L. (2000). Effects of economic prosperity on numbers of threatened species. Conservation Biology, 15(4), 1021-1029.

Newey, W.K., \& West, K.D. (1987). A simple, positive semi-definite, heteroskedasticity and autocorrelation consistent covariance matrix. Econometrica, 55, 703-708.

Porwal, M.C., Padalia, H., \& Roy, P.S. (2012). Impact of tsunami on the forest and biodiversity richness in Nicobar Islands (Andaman and Nicobar Islands), India. Biodiversity Conservation, 21, 1267 1287.

Reed, D.H. (2012). Impact of climate change on biodiversity. In W.Y. Chen, J. Seiner, T. Suzuki \& M. Lackner (eds). Handbook of Climate Change Mitigation. New York: Springer-Verlag. pp. 505530.

Rinawati, F., Stein, K., \& Lindner, A. (2013). Climate change impacts on biodiversity - The setting of a lingering global crisis. Diversity, 5, 114-123. 
Rosales, J. (2008). Economic growth, climate change, biodiversity loss: Distributive justice for the global North and South. Conservation Biology, 22(6), 1409-1417.

Sarkar, S. (2012). Impact of global warming on biodiversity. The Science Probe, 1(2), 22-33.

Secretariat of the Convention on Biological Diversity. (2010). Global Biodiversity Outlook 3. Montréal: The Secretariat of the Convention on Biological Diversity.

Shandra, J.M. (2007). The world polity and deforestation: A quantitative, cross-national analysis. International Journal of Comparative Sociology, 48(1), 5-27.

Shandra, J.M., McKinney, L.A., Leckband, C., \& London, B. (2010). Debt, structural adjustment and biodiversity loss: A cross-national analysis of threatened mammals and birds. Research in Human Ecology, 17(1), 18-33.

Shandra, J.M., Rademacher, H., \& Coburn, C. (2016). The World Bank and organized hypocrisy? A cross-national analysis of structural adjustment and forest loss. Environmental Sociology, 2(2), 192-207.

Shandra, J.M., Shircliff, E., \& London, B. (2011). The International Monetary Fund, World Bank and structural adjustment: A cross-national analysis of forest loss. Social Science Research, 40, 210225.

Sintayehu, D.W. (2018). Impact of climate change on biodiversity and associated key ecosystem services in Africa: A systemic review. Ecosystem Health and Sustainability, 4(9), 225-239.

Smith, R.J., Muir, R.D.J., Walpole, M.J., Balmford, A., \& Leader-Williams, N. (2003). Governance and the loss of biodiversity. Nature, 426, 67-70.

Suh, S. (2006). Are services better for climate change? Environmental Science \& Technology, 40, 65556560.

Swiderska, K., Roe, D., Siegele, L., \& Grieg-Gran, M. (2008). The Governance of Nature and the Nature of Governance: Policy that Works for Biodiversity and Livelihoods. London: International Institute for Environment and Development (iied).

Thomas, C.D., Cameron, A., Green, R.E., Bakkenes, L., Beaumont, J., Collingham, Y.C., Erasmus, B.F.N., et al. (2004). Extinction risk from climate change. Nature, 427, 145-148.

Tol, R.S.J. (2009). The economic effects of climate change. Journal of Economic Perspectives, 23(2), 2951.

Umemiya, C., Rametsteiner, E., \& Kraxner, F. (2010). Quantifying the impacts of the quality of governance on deforestation. Environmental Science \& Policy, 13, 695-701.

UNEP (United Nations Environment Programme). (2002). State of the Environment and Policy Retrospective: 1972-2002. London: Earthscan.

UNU-IAS (United Nations University Institute of Advanced Studies). (2010). Climate and Human-related Drivers of Biodiversity Decline in Southeast Asia. UNU-IAS Policy Report. Japan: United Nations University Institute of Advanced Studies.

WWF (World Wildlife Fund). (2016). Living Planet Report 2016: Risk and Resilience in a New Era. Switzerland: WWF International. 
Table 1: List of 98 Countries included in the Study

\begin{tabular}{|l|l|l|l|l|l|}
\hline Algeria & Cambodia & Gambia & Kenya & New Zealand & South Africa \\
\hline Angola & Cameroon & Germany & Korea & Nicaragua & Spain \\
\hline Argentina & Canada & Ghana & Lebanon & Nigeria & Swaziland \\
\hline Australia & Chad & Greece & Lesotho & Norway & Sweden \\
\hline Austria & Chile & Guatemala & Libya & Oman & Switzerland \\
\hline Bahrain & China & Guyana & Madagascar & Pakistan & Thailand \\
\hline Bangladesh & Colombia & Honduras & Malawi & Panama & Trinidad \\
\hline Barbados & Costa Rica & Hungary & Malaysia & Paraguay & Tunisia \\
\hline Belgium & Cyprus & Iceland & Mali & Peru & Turkey \\
\hline Benin & Denmark & India & Mauritania & Philippines & United Emirate \\
\hline Bolivia & $\begin{array}{l}\text { Dominic } \\
\text { Rep }\end{array}$ & Indonesia & Mexico & Poland & United Kingdom \\
\hline Botswana & Ecuador & Ireland & Mongolia & Portugal & Uruguay \\
\hline Brazil & Egypt & Israel & Morocco & Puerto Rico & United States \\
\hline Bulgaria & El Salvador & Italy & Mozambique & Rwanda & Venezuela \\
\hline $\begin{array}{l}\text { Burkina } \\
\text { Faso }\end{array}$ & Finland & Jamaica & Nepal & Saudi Arabia & Vietnam \\
\hline Burundi & France & Japan & Netherlands & Senegal & Zambia \\
\hline & & & & Singapore & Zimbabwe \\
\hline
\end{tabular}

Table 2: Determinants of Threatened Species

\begin{tabular}{|c|c|c|c|c|c|c|}
\hline Independent variables & Birds & Fishes & Mammals & Plants & Reptiles & $\begin{array}{l}\text { Total } \\
\text { species }\end{array}$ \\
\hline \multicolumn{7}{|l|}{ Panel A: Regressions } \\
\hline \multirow[t]{2}{*}{ Constant } & $8.1614 * * *$ & $\begin{array}{l}- \\
7.6592 * * \\
*\end{array}$ & $6.7580 * * *$ & $20.578 * * *$ & $-11.777 * * *$ & $9.3025 * * *$ \\
\hline & $(-4.0055)$ & $(-5.2778)$ & $(-4.3108)$ & $(-8.9017)$ & $(-6.2776)$ & $(-6.5262)$ \\
\hline \multirow[t]{2}{*}{ Disaster Occurrences } & $0.0537 * * *$ & $0.0216 * *$ & $0.0425 * *$ & 0.0349 & $0.0558 * * *$ & $0.0330 * *$ \\
\hline & $(3.4888)$ & $(2.1208)$ & $(2.3667)$ & $(1.6195)$ & $(3.4100)$ & $(2.4464)$ \\
\hline \multirow[t]{2}{*}{ Temperature } & $1.0736^{* * *}$ & $\begin{array}{l}0.9361 * * \\
*\end{array}$ & $0.7975 * * *$ & $1.4377 * * *$ & $1.6956^{* * *}$ & $1.0827 * * *$ \\
\hline & $(3.3393)$ & $(3.5463)$ & $(3.2627)$ & $(4.7552)$ & $(5.4413)$ & $(5.1359)$ \\
\hline \multirow[t]{2}{*}{ Precipitation } & $0.1919 * * *$ & 0.1518 & 0.1396 & $1.0299 * * *$ & 0.1909 & $0.3860 * * *$ \\
\hline & $(2.9484)$ & $(1.5527)$ & $(1.8599)$ & $(7.2199)$ & $(1.8354)$ & $(4.9843)$ \\
\hline \multirow[t]{2}{*}{ Real GDP } & $0.2683 * * *$ & $\begin{array}{l}0.3009 * * \\
*\end{array}$ & $0.2601 * * *$ & $0.5066^{* * *}$ & $0.2928 * * *$ & $0.3143 * * *$ \\
\hline & $(4.9487)$ & $(7.0657)$ & $(6.0758)$ & $(7.0708)$ & $(4.6428)$ & $(7.9158)$ \\
\hline \multirow[t]{2}{*}{ Government Effective } & $\begin{array}{l}- \\
0.4827 * * *\end{array}$ & 0.0057 & $\overline{0}-5763 * * *$ & $\begin{array}{l}- \\
0.7773 * * *\end{array}$ & -0.2756 & $\overline{0.4150 * * *}$ \\
\hline & $(-2.7553)$ & $(0.0398)$ & $(-4.7855)$ & $(-3.2192)$ & $(-1.4759)$ & $(-3.0923)$ \\
\hline Adj R-squared & 0.5481 & 0.2914 & 0.5254 & 0.5600 & 0.4481 & 0.5885 \\
\hline SER & 0.7611 & 1.0088 & 0.7091 & 1.3392 & 1.0595 & 0.7203 \\
\hline
\end{tabular}




\begin{tabular}{|c|c|c|c|c|c|c|}
\hline OLS, BPG test, $\chi^{2}(1)$ & 0.065 & $0.0438 * *$ & 0.4906 & 0.5313 & 0.8317 & 0.5622 \\
\hline Obs & 98 & 98 & 98 & 98 & 98 & 98 \\
\hline \multicolumn{7}{|l|}{ Panel B: Outliers } \\
\hline DFITS & $\begin{array}{l}\text { Iceland, } \\
\text { Mongolia, } \\
\text { New } \\
\text { Zealand, } \\
\text { Philippines } \\
\text { Switzerlan } \\
\text { d }\end{array}$ & $\begin{array}{l}\text { Bolivia, } \\
\text { Brazil, } \\
\text { Chad, } \\
\text { Iceland, } \\
\text { Libya, } \\
\text { Mongolia } \\
\text { Paraguay }\end{array}$ & $\begin{array}{l}\text { Australia, } \\
\text { Iceland, } \\
\text { Libya, } \\
\text { Malaysia, } \\
\text { Mongolia, } \\
\text { Philippine } \\
\text { s, Saudi } \\
\text { Arabia }\end{array}$ & $\begin{array}{l}\text { China, } \\
\text { Cyprus, } \\
\text { Libya, } \\
\text { Philippine } \\
\text { s, UAE }\end{array}$ & $\begin{array}{l}\text { Iceland, } \\
\text { Libya, } \\
\text { Madagasca } \\
\text { r, } \\
\text { Philippines, } \\
\text { Saudi } \\
\text { Arabia }\end{array}$ & $\begin{array}{l}\text { China, } \\
\text { Ecuador, } \\
\text { Iceland, } \\
\text { Libya, } \\
\text { Malaysia, } \\
\text { Mongolia, } \\
\text { Philippine } \\
\text { s, }\end{array}$ \\
\hline
\end{tabular}

Notes: Asterisks $* * *, * *$ denote statistically significant at the 1\%, and 5\% level, respectively. Figures in round bracket $(. .$.$) are t-statistics; while figures in square bracket [...] are p-values. SER denotes standard$ error of regression. BPG denote Breusch-Pagan-Godfrey test for heteroskedasticity test. DFITS is the scaled difference between the predicted responses from the model constructed from all of the data and the predicted responses from the model constructed by setting the i-th observation aside. It is similar to Cook's distance. Unlike Cook's distance, it does not look at all of the predicted values with the i-th observation set aside. Some analysts suggest investigating observations for which |DFITSi| is greater than $2(p+1) /(n-p-1)$.

Table 3: Quantile Regression Estimates for Threatened Species

\begin{tabular}{|c|c|c|c|c|c|c|}
\hline Quantiles & Constant & $\begin{array}{c}\text { Disaster } \\
\text { Occurrences }\end{array}$ & Temperature & Precipitation & Real GDP & $\begin{array}{l}\text { Government } \\
\text { Effective }\end{array}$ \\
\hline \multicolumn{7}{|c|}{ Panel A: Birds } \\
\hline \multirow[t]{3}{*}{$Q(0.10)$} & $-6.5693 * *$ & $0.0661 * * *$ & $1.0845^{* *}$ & 0.0697 & $0.1969 * * *$ & $-0.6013^{* *}$ \\
\hline & $(-2.5039)$ & $(4.6188)$ & $(2.1305)$ & $(0.7751)$ & (3.1584) & $(-2.5505)$ \\
\hline & \multicolumn{2}{|c|}{ Pseudo $R^{2}=0.4398$} & & & & \\
\hline \multirow[t]{3}{*}{$Q(0.20)$} & $-7.8152^{* * *}$ & $0.0525^{* * *}$ & $1.0428 * * *$ & 0.0895 & $0.2626 * * *$ & $-0.5198 * * *$ \\
\hline & $(-3.2952)$ & (3.4549) & $(2.9444)$ & $(0.9980)$ & $(4.3315)$ & $(-2.7433)$ \\
\hline & \multicolumn{2}{|c|}{ Pseudo $R^{2}=0.4187$} & & & & \\
\hline \multirow[t]{3}{*}{$Q(0.30)$} & $-8.7269 * * *$ & $0.0410 * *$ & $1.3685^{* * *}$ & 0.1605 & $0.2509 * * *$ & $-0.4146 * *$ \\
\hline & $(-3.8128)$ & $(2.5060)$ & (4.0769) & $(1.7725)$ & $(4.0017)$ & $(-2.2353)$ \\
\hline & \multicolumn{2}{|c|}{ Pseudo $R^{2}=0.3781$} & & & & \\
\hline \multirow[t]{3}{*}{$Q(0.40)$} & $-9.2812^{* * *}$ & $0.0523 * *$ & $1.4839 * * *$ & $0.1930 * *$ & $0.2554 * * *$ & $-0.3967 * *$ \\
\hline & $(-3.9882)$ & $(2.0254)$ & $(4.3714)$ & $(2.0800)$ & $(3.7800)$ & $(-1.9971)$ \\
\hline & \multicolumn{2}{|c|}{ Pseudo $R^{2}=0.3664$} & & & & \\
\hline \multirow[t]{3}{*}{$Q(0.50)$} & $-9.8639 * * *$ & 0.0500 & $1.4311^{* * *}$ & $0.2466 * *$ & $0.2774 * * *$ & -0.3889 \\
\hline & $(-3.7528)$ & $(1.2679)$ & $(4.4393)$ & $(2.5830)$ & (3.4251) & $(-1.9141)$ \\
\hline & \multicolumn{2}{|c|}{ Pseudo $R^{2}=0.3733$} & & & & \\
\hline \multirow[t]{3}{*}{$Q(0.60)$} & $-8.6869 * * *$ & 0.0736 & $1.1393 * * *$ & $0.2943 * * *$ & $0.2579 * * *$ & -0.4408 \\
\hline & $(-2.7422)$ & $(1.5672)$ & $(2.7157)$ & $(2.9224)$ & $(2.7117)$ & $(-1.9083)$ \\
\hline & \multicolumn{2}{|c|}{ Pseudo $R^{2}=0.3846$} & & & & \\
\hline \multirow[t]{3}{*}{$Q(0.70)$} & $-10.116^{* * *}$ & 0.0189 & $0.8727^{* * *}$ & $0.3975 * * *$ & $0.3367^{* * *}$ & $-0.5359 * * *$ \\
\hline & $(-5.0296)$ & $(1.3171)$ & $(2.1685)$ & $(4.6517)$ & $(5.7648)$ & $(-2.8945)$ \\
\hline & \multicolumn{2}{|c|}{ Pseudo $R^{2}=0.3927$} & & & & \\
\hline \multirow[t]{3}{*}{$Q(0.80)$} & $-9.7447 * * *$ & 0.0368 & $1.0034 * * *$ & $0.4062 * * *$ & $0.3057^{* * *}$ & $-0.4112 * *$ \\
\hline & $(-5.2826)$ & $(1.0390)$ & $(2.7741)$ & $(4.8982)$ & $(4.7146)$ & $(-2.0093)$ \\
\hline & \multicolumn{2}{|c|}{ Pseudo $R^{2}=0.3882$} & & & & \\
\hline$Q(0.90)$ & $-7.8197 * * *$ & 0.0017 & 0.3712 & $0.4632 * * *$ & $0.3065 * * *$ & $-0.5708^{* * *}$ \\
\hline
\end{tabular}




\begin{tabular}{|c|c|c|c|c|c|c|}
\hline & $(-2.7511)$ & $(0.1607)$ & $(0.5683)$ & (6.0031) & (5.3778) & $(-2.9536)$ \\
\hline & \multicolumn{2}{|c|}{ Pseudo $R^{2}=0.3591$} & & & & \\
\hline \multicolumn{7}{|c|}{ Panel B: Fishes } \\
\hline \multirow[t]{3}{*}{$Q(0.10)$} & $-15.266 * * *$ & $0.0314 * *$ & $0.8611^{* *}$ & 0.4130 & $0.4962 * * *$ & 0.0219 \\
\hline & $(-6.4312)$ & $(2.3538)$ & $(2.3904)$ & $(1.6305)$ & $(5.4871)$ & $(0.1006)$ \\
\hline & \multicolumn{2}{|c|}{ Pseudo $R^{2}=0.3394$} & & & & \\
\hline \multirow[t]{3}{*}{$Q(0.20)$} & $-12.977 * * *$ & $0.0295 * *$ & $1.0128 * * *$ & 0.2652 & $0.4408 * * *$ & -0.0283 \\
\hline & $(-5.3906)$ & $(2.1401)$ & (3.4228) & (1.6769) & $(5.0622)$ & $(-0.1297)$ \\
\hline & \multicolumn{2}{|c|}{ Pseudo $R^{2}=0.2624$} & & & & \\
\hline \multirow[t]{3}{*}{$Q(0.30)$} & $-9.9772 * * *$ & 0.0209 & $1.0133 * * *$ & 0.2360 & $0.3462 * * *$ & -0.0447 \\
\hline & $(-3.2383)$ & $(1.3168)$ & (3.1819) & $(1.5353)$ & $(3.6182)$ & $(-0.2097)$ \\
\hline & \multicolumn{2}{|c|}{ Pseudo $R^{2}=0.2017$} & & & & \\
\hline \multirow[t]{3}{*}{$Q(0.40)$} & $-6.7056^{*}$ & 0.0146 & $1.1917^{* * *}$ & 0.1016 & $0.2463 * * *$ & 0.1576 \\
\hline & $(-1.9372)$ & $(0.7075)$ & $(2.3631)$ & $(0.5699)$ & $(2.9378)$ & $(0.6675)$ \\
\hline & \multicolumn{2}{|c|}{ Pseudo $R^{2}=0.1778$} & & & & \\
\hline \multirow[t]{3}{*}{$Q(0.50)$} & -4.7197 & 0.0363 & $1.0379 * *$ & 0.0645 & $0.2032 * *$ & 0.0049 \\
\hline & $(-1.4944)$ & $(1.1356)$ & $(2.0370)$ & $(0.4455)$ & $(2.5218)$ & $(0.0221)$ \\
\hline & \multicolumn{2}{|c|}{ Pseudo $R^{2}=0.2072$} & & & & \\
\hline \multirow[t]{3}{*}{$Q(0.60)$} & -4.0084 & 0.0450 & 0.9445 & 0.0407 & $0.1993 * *$ & -0.1138 \\
\hline & $(-1.4299)$ & $(1.2692)$ & $(1.9255)$ & $(0.3236)$ & $(2.5539)$ & $(-0.5286)$ \\
\hline & \multicolumn{2}{|c|}{ Pseudo $R^{2}=0.2330$} & & & & \\
\hline \multirow[t]{3}{*}{$Q(0.70)$} & $-4.8981^{*}$ & 0.0323 & $0.9675^{* *}$ & 0.1066 & $0.2219 * * *$ & -0.2064 \\
\hline & $(-1.7541)$ & $(0.9471)$ & $(2.0678)$ & $(0.8952)$ & $(2.8158)$ & $(-0.9229)$ \\
\hline & \multicolumn{2}{|c|}{ Pseudo $R^{2}=0.2591$} & & & & \\
\hline \multirow[t]{3}{*}{$Q(0.80)$} & -2.5416 & 0.0548 & $0.7544^{* *}$ & 0.0272 & $0.1798 * * *$ & -0.1320 \\
\hline & $(-1.3125)$ & $(1.3955)$ & $(2.1018)$ & $(0.2748)$ & $(2.8788)$ & $(-0.5797)$ \\
\hline & \multicolumn{2}{|c|}{ Pseudo $R^{2}=0.2821$} & & & & \\
\hline \multirow[t]{3}{*}{$Q(0.90)$} & $-3.4942 *$ & 0.0358 & 0.4471 & 0.1124 & $0.2416 * * *$ & $-0.4218 * *$ \\
\hline & $(-1.7377)$ & $(1.0886)$ & $(1.4629)$ & $(1.2934)$ & $(3.7210)$ & $(-2.1996)$ \\
\hline & \multicolumn{2}{|c|}{ Pseudo $R^{2}=0.2937$} & & & & \\
\hline
\end{tabular}

Notes: Asterisks $* * * * *$ denote statistically significant at $1 \%$ and $5 \%$ respectively. All variables are in natural logarithm except for disaster occurrences. The mean value for natural disaster occurrences is 2.826531 .

Table 3: Quantile Regression Estimates for Threatened Species (continue)

\begin{tabular}{|c|l|l|l|l|l|l|}
\hline Quantiles & Constant & $\begin{array}{c}\text { Disaster } \\
\text { Occurrences }\end{array}$ & Temperature & Precipitation & Real GDP & $\begin{array}{l}\text { Government } \\
\text { Effective }\end{array}$ \\
\hline \multicolumn{2}{|l|}{ Panel C: Mammals } & & & & & \\
\hline$Q(0.10)$ & -5.0082 & $0.0518^{* * *}$ & 0.5936 & -0.0208 & $0.2206^{* *}$ & $-0.7315^{* * *}$ \\
\hline & $(-1.3509)$ & $(3.5111)$ & $(1.1050)$ & $(-0.1666)$ & $(2.4280)$ & $(-2.6711)$ \\
\hline & Pseudo $R^{2}=0.3540$ & & & & \\
\hline$Q(0.20)$ & $-8.7003^{* *}$ & 0.0339 & 0.9953 & 0.0750 & $0.3072^{* * *}$ & $-0.5411^{* *}$ \\
\hline & $(-2.2137)$ & $(1.9701)$ & $(1.8291)$ & $(0.4809)$ & $(3.6139)$ & $(-2.1437)$ \\
\hline$Q(0.30)$ & Pseudo $R^{2}=0.3268$ & & & & \\
\hline & $-7.3830^{*}$ & 0.0324 & 0.9546 & -0.0200 & $0.2923^{* * *}$ & $-0.6091^{* *}$ \\
\hline & $(-1.7737)$ & $(1.6725)$ & $(1.5866)$ & $(-0.1447)$ & $(3.1324)$ & $(-2.4763)$ \\
\hline$Q(0.40)$ & Pseudo $R^{2}=0.2990$ & & & & \\
\hline & $-8.1962^{* *}$ & 0.0211 & $1.0652^{* *}$ & 0.1354 & $0.2820^{* * *}$ & $-0.5893^{* * *}$ \\
\hline & $(-2.5429)$ & $(1.2178)$ & $(2.3372)$ & $(1.0762)$ & $(3.6711)$ & $(-3.2530)$ \\
\hline
\end{tabular}




\begin{tabular}{|c|c|c|c|c|c|c|}
\hline$Q(0.50)$ & $-7.3135 * *$ & 0.0688 & $1.0897 * *$ & 0.1082 & $0.2549 * * *$ & -0.4358 \\
\hline & \multicolumn{2}{|c|}{\begin{tabular}{|l|l|}
$(-2.2322)$ & $(1.2924)$ \\
\end{tabular}} & $(2.2671)$ & $(0.7927)$ & $(2.9380)$ & $(-1.9340)$ \\
\hline & \multicolumn{2}{|c|}{ Pseudo $R^{2}=0.3090$} & & & & \\
\hline \multirow{3}{*}{$Q(0.60)$} & $-8.1165 * * *$ & 0.0568 & $1.0662 * *$ & 0.2137 & $0.2696 * * *$ & $-0.5646 * *$ \\
\hline & $(-2.6654)$ & (1.1479) & $(2.4451)$ & $(1.7348)$ & $(3.2186)$ & $(-2.4853)$ \\
\hline & \multicolumn{2}{|c|}{ Pseudo $R^{2}=0.3392$} & & & & \\
\hline \multirow[t]{3}{*}{$Q(0.70)$} & $-7.6464 * *$ & 0.0408 & 0.9102 & 0.2185 & $0.2770 * * *$ & $-0.5964 * * *$ \\
\hline & $(-2.5926)$ & $(0.8812)$ & $(1.7450)$ & $(1.9414)$ & $(3.4776)$ & $(-2.6752)$ \\
\hline & \multicolumn{2}{|c|}{ Pseudo $R^{2}=0.3708$} & & & & \\
\hline \multirow[t]{3}{*}{$Q(0.80)$} & $-5.9908 * *$ & 0.0577 & 0.6792 & $0.2332 * *$ & $0.2416 * * *$ & $-0.7179 * * *$ \\
\hline & $(-2.5981)$ & $(1.2305)$ & $(1.7506)$ & $(2.4630)$ & $(3.1022)$ & $(-3.6862)$ \\
\hline & \multicolumn{2}{|c|}{ Pseudo $R^{2}=0.3964$} & & & & \\
\hline \multirow[t]{3}{*}{$Q(0.90)$} & $-4.1287 * *$ & 0.0763 & 0.4424 & 0.1910 & $0.2155^{* *}$ & $-0.5929 * * *$ \\
\hline & \multirow{2}{*}{\multicolumn{2}{|c|}{\begin{tabular}{l|l}
$(-2.2060)$ & $(1.3009)$ \\
Pseudo $R^{2}=0.3954$
\end{tabular}}} & $(1.5466)$ & $(1.8892)$ & $(2.5888)$ & $(-2.9412)$ \\
\hline & & & & & & \\
\hline \multicolumn{7}{|c|}{ Panel D: Plants } \\
\hline \multirow[t]{3}{*}{$Q(0.10)$} & $-16.556 * * *$ & $0.0957 * * *$ & 0.3395 & $0.5956 * * *$ & $0.5211^{* * *}$ & $-1.2322 * * *$ \\
\hline & $(-4.0829)$ & $(3.5935)$ & $(0.6144)$ & $(3.0470)$ & $(3.8298)$ & $(-3.7037)$ \\
\hline & \multicolumn{2}{|c|}{ Pseudo $R^{2}=0.3603$} & & & & \\
\hline \multirow[t]{3}{*}{$Q(0.20)$} & $-16.991 * * *$ & $0.0702^{* *}$ & 0.8710 & $0.9160 * * *$ & $0.4093 * * *$ & $0.2000 * *$ \\
\hline & $(-3.7250)$ & $(2.0834)$ & $(1.4148)$ & $(3.3489)$ & $(3.0535)$ & $(-0.8570)$ \\
\hline & \multicolumn{2}{|c|}{ Pseudo $R^{2}=0.3340$} & & & & \\
\hline \multirow[t]{3}{*}{$Q(0.30)$} & $-22.288 * * *$ & 0.0292 & $1.4077 * * *$ & $1.1648^{* * *}$ & $0.5275^{* * *}$ & $-0.8631^{* * *}$ \\
\hline & $(-7.5665)$ & $(1.0728)$ & $(3.0497)$ & $(6.3396)$ & $(6.1508)$ & $(-2.6949)$ \\
\hline & Pseudo $R^{2}$ & 0.3489 & & & & \\
\hline$Q(0.40)$ & $-22.220 * * *$ & 0.0201 & $1.1459 * *$ & $1.1853 * * *$ & $0.5642 * * *$ & $-0.8248 * *$ \\
\hline & $(-7.3196)$ & $(0.7006)$ & $(2.4574)$ & $(6.0666)$ & $(6.0438)$ & $(-2.4235)$ \\
\hline & Pseudo $R^{2}$ & 0.3810 & & & & \\
\hline$Q(0.50)$ & $-21.292 * * *$ & 0.0183 & $1.3961 * * *$ & $1.0724 * * *$ & $0.5327 * * *$ & -0.6962 \\
\hline & $(-6.8426)$ & $(0.6254)$ & $(2.7365)$ & $(4.9140)$ & $(5.4457)$ & $(-1.8241)$ \\
\hline & Pseudo $R^{2}$ & 0.3985 & & & & \\
\hline$Q(0.60)$ & $-19.632 * * *$ & 0.0291 & $1.3985 * *$ & $0.9701 * * *$ & $0.5000 * * *$ & -0.5826 \\
\hline & $(-6.1819)$ & $(1.0118)$ & $(2.6024)$ & $(4.1522)$ & $(4.9414)$ & $(-1.4782)$ \\
\hline & Pseudo $R^{2}$ & 0.3891 & & & & \\
\hline$Q(0.70)$ & $-21.760 * * *$ & -0.0035 & $2.0648 * * *$ & $0.8617 * * *$ & $0.5586 * * *$ & -0.5079 \\
\hline & $(-5.9866)$ & $(-0.1318)$ & $(3.2234)$ & $(2.9897)$ & $(4.1183)$ & $(-0.9668)$ \\
\hline & Pseudo $R^{2}$ & 0.3785 & & & & \\
\hline$Q(0.80)$ & $-18.882 * * *$ & -0.0144 & $2.6234^{* * *}$ & $0.7802 * * *$ & $0.4155^{* * *}$ & -0.0449 \\
\hline & $(-5.6219)$ & $(-0.5946)$ & (3.5744) & $(2.6646)$ & $(3.0714)$ & $(-0.0867)$ \\
\hline & Pseudo $R^{2}$ & 0.3789 & & & & \\
\hline$Q(0.90)$ & $-18.690 * * *$ & 0.0732 & $2.5790 * * *$ & $0.9314 * * *$ & 0.3897 & -0.3108 \\
\hline & $(-2.7768)$ & $(0.6480)$ & $(3.6670)$ & $(2.8446)$ & $(1.4831)$ & $(-0.4446)$ \\
\hline & Pseudo $R^{2}$ & 0.3514 & & & & \\
\hline
\end{tabular}

Notes: Asterisks $* * * * *$ denote statistically significant at $1 \%$ and $5 \%$ respectively. All variables are in natural logarithm except for disaster occurrences. The mean value for natural disaster occurrences is 2.826531 . 
Table 3: Quantile Regression Estimates for Threatened Species (continue)

\begin{tabular}{|c|c|c|c|c|c|c|}
\hline Quantiles & Constant & \begin{tabular}{|c} 
Disaster \\
Occurrences
\end{tabular} & Temperature & Precipitation & Real GDP & $\begin{array}{l}\text { Government } \\
\text { Effective }\end{array}$ \\
\hline \multicolumn{7}{|c|}{ Panel E: Reptiles } \\
\hline \multirow[t]{3}{*}{$Q(0.10)$} & $-11.245^{*}$ & $0.0889 * * *$ & 1.0212 & 0.1118 & $0.3146 * *$ & -0.5200 \\
\hline & $(-1.8123)$ & $(3.3670)$ & $(1.2775)$ & $(0.3065)$ & (2.6053) & $(-1.2971)$ \\
\hline & \multicolumn{2}{|c|}{$P_{\text {seudo }}{ }^{2}=0.2172$} & & & & \\
\hline \multirow{3}{*}{$Q(0.20)$} & $-16.073 * * *$ & $0.0588 * *$ & $1.7772^{* *}$ & 0.4050 & $0.3579 * * *$ & -0.2921 \\
\hline & $(-3.4795)$ & $(2.4113)$ & (2.1929) & (1.4085) & (3.5428) & $(-0.6999)$ \\
\hline & \multicolumn{2}{|c|}{ Pseudo $R^{2}=0.3173$} & & & & \\
\hline \multirow[t]{3}{*}{$Q(0.30)$} & $-15.834 * * *$ & $0.0457^{* *}$ & $1.9748^{* * *}$ & 0.4100 & $0.3405^{* * *}$ & -0.2682 \\
\hline & $(-3.8855)$ & $(2.0898)$ & (3.0746) & $(1.7762)$ & $(3.2166)$ & $(-0.7419)$ \\
\hline & \multicolumn{2}{|c|}{ Pseudo $R^{2}=0.3220$} & & & & \\
\hline \multirow{3}{*}{$Q(0.40)$} & $-15.422 * * *$ & 0.0363 & $2.5464^{* * *}$ & 0.2812 & $0.3029 * * *$ & -0.0039 \\
\hline & $(-3.9912)$ & $(1.5760)$ & $(4.0231)$ & $(1.1866)$ & (3.0054) & $(-0.0122)$ \\
\hline & \multicolumn{2}{|c|}{ Pseudo $R^{2}=0.2956$} & & & & \\
\hline \multirow[t]{3}{*}{$Q(0.50)$} & $-11.944 * * *$ & 0.0419 & $1.6434^{* * *}$ & 0.2416 & $0.2987 * * *$ & -0.3729 \\
\hline & $(-4.0778)$ & $(1.8225)$ & $(3.8567)$ & $(1.4443)$ & (3.0178) & $(-1.3734)$ \\
\hline & \multicolumn{2}{|c|}{ Pseudo $R^{2}=0.3024$} & & & & \\
\hline \multirow[t]{3}{*}{$Q(0.60)$} & $-10.763^{* * *}$ & 0.0395 & $1.6357^{* * *}$ & 0.2742 & $0.2503^{* * *}$ & -0.2456 \\
\hline & $(-4.2298)$ & $(1.7573)$ & $(4.2269)$ & (1.7059) & $(2.8657)$ & $(-1.0088)$ \\
\hline & \multicolumn{2}{|c|}{ Pseudo $R^{2}=0.3024$} & & & & \\
\hline \multirow[t]{3}{*}{$Q(0.70)$} & $-10.808 * * *$ & 0.0217 & $1.8564^{* * *}$ & 0.1336 & $0.2778^{* * *}$ & -0.2249 \\
\hline & $(-4.4091)$ & $(1.0868)$ & $(4.1143)$ & $(0.9619)$ & (3.3489) & $(-0.9657)$ \\
\hline & \multicolumn{2}{|c|}{ Pseudo $R^{2}=0.3035$} & & & & \\
\hline \multirow[t]{3}{*}{$Q(0.80)$} & $-9.0716 * * *$ & 0.0440 & $1.4533^{* * *}$ & 0.0869 & $0.2753^{* * *}$ & -0.2547 \\
\hline & $(-3.8578)$ & (1.5605) & (2.9520) & $(0.7173)$ & (3.4547) & $(-1.1280)$ \\
\hline & \multicolumn{2}{|c|}{ Pseudo $^{2}=0.3061$} & & & & \\
\hline \multirow[t]{3}{*}{$Q(0.90)$} & $-9.0292 * *$ & 0.0796 & $1.6689^{* * *}$ & 0.0198 & 0.2807 & -0.2559 \\
\hline & $(-2.3204)$ & $(0.5814)$ & (2.7299) & $(0.1200)$ & $(1.8631)$ & $(-0.8230)$ \\
\hline & \multicolumn{2}{|c|}{ Pseudo $R^{2}=0.2697$} & & & & \\
\hline \multicolumn{7}{|c|}{\begin{tabular}{lll|}
$\begin{array}{l}\text { Panel F: } \\
\text { species }\end{array}$ & Total \\
\end{tabular}} \\
\hline \multirow[t]{3}{*}{$Q(0.10)$} & $-9.5806 * * *$ & $0.0451^{* * *}$ & $0.8439 * *$ & $0.3071^{* *}$ & $0.3424 * * *$ & -0.3218 \\
\hline & $(-3.9807)$ & (3.4542) & $(2.2250)$ & $(2.4300)$ & $(6.0696)$ & $(-1.5805)$ \\
\hline & \multicolumn{2}{|c|}{ Pseudo $R^{2}=0.3858$} & & & & \\
\hline \multirow[t]{3}{*}{$Q(0.20)$} & $-9.3872 * * *$ & $0.0381 * * *$ & $0.9828 * * *$ & $0.3621^{* * *}$ & $0.3106^{* * *}$ & -0.2613 \\
\hline & $(-3.7076)$ & (2.6902) & $(3.0500)$ & $(2.8932)$ & $(5.2260)$ & $(-1.7312)$ \\
\hline & Pseudo $R^{2}$ & 0.4046 & & & & \\
\hline$Q(0.30)$ & $-9.8044 * * *$ & 0.0303 & $1.1411^{* * *}$ & $0.4326^{* * *}$ & $0.2963^{* * *}$ & -0.2208 \\
\hline & $(-3.4654)$ & (1.8342) & (3.3075) & $(3.0803)$ & $(4.6444)$ & $(-1.4167)$ \\
\hline & Pseudo $R^{2}$ & 0.4004 & & & & \\
\hline$Q(0.40)$ & $-9.4865 * * *$ & \begin{tabular}{|l|}
0.0274 \\
\end{tabular} & $1.1033^{* * *}$ & $0.4302^{* * *}$ & $0.2938^{* * *}$ & -0.2930 \\
\hline & $(-3.2667)$ & $(1.5424)$ & (3.0573) & $(2.8924)$ & $(4.4917)$ & $(-1.6565)$ \\
\hline & Pseudo $R^{2}$ & 0.3864 & & & & \\
\hline$Q(0.50)$ & $-9.5595 * * *$ & 0.0338 & $1.2057^{* * *}$ & $0.3357^{* * *}$ & $0.3230^{* * *}$ & $-0.4816^{* *}$ \\
\hline & \begin{tabular}{|l|}
$(-3.7135)$ \\
\end{tabular} & $(1.5060)$ & (3.1261) & (2.6243) & $(4.8302)$ & $(-2.2151)$ \\
\hline & Pseudo $R^{2}$ & 0.3919 & & & & \\
\hline$Q(0.60)$ & $-9.6297 * * *$ & 0.0411 & $1.1525^{* * *}$ & $0.3716^{* * *}$ & $0.3292^{* * *}$ & $-0.6141 * *$ \\
\hline
\end{tabular}




\begin{tabular}{|l|l|l|l|l|l|l|}
\hline & $(-3.1597)$ & $(1.0870)$ & $(3.0230)$ & $(3.1701)$ & $(3.7606)$ & $(-2.6302)$ \\
\hline & Pseudo $R^{2}=0.4030$ & & & & \\
\hline$Q(0.70)$ & $-8.4388^{* * *}$ & 0.0401 & $1.1861^{* * *}$ & $0.3674^{* * *}$ & $0.2846^{* * *}$ & $-0.5804^{* *}$ \\
\hline & $(-3.4139)$ & $(1.1603)$ & $(3.4072)$ & $(3.0324)$ & $(3.6210)$ & $(-2.4198)$ \\
\hline & Pseudo $R^{2}=0.4004$ & & & & \\
\hline$Q(0.80)$ & $-7.5952^{* * *}$ & 0.0522 & $1.0212^{* * *}$ & $0.3434^{* * *}$ & $0.2848^{* * *}$ & -0.3513 \\
\hline & $(-3.3891)$ & $(1.1530)$ & $(2.7553)$ & $(2.7739)$ & $(3.0381)$ & $(-1.0268)$ \\
\hline & Pseudo $R^{2}=0.4110$ & & & & \\
\hline$Q(0.90)$ & $-10.928^{* * *}$ & -0.0003 & $0.9561^{* * *}$ & $0.5628^{* * *}$ & $0.3918^{* * *}$ & $-0.6799^{* *}$ \\
\hline & $(-3.4668)$ & $(-0.0100)$ & $(3.0360)$ & $(3.6348)$ & $(3.1968)$ & $(-2.2238)$ \\
\hline
\end{tabular}

Notes: Asterisks $* * * * *$ denote statistically significant at $1 \%$ and $5 \%$ respectively. All variables are in natural logarithm except for disaster occurrences. The mean value for natural disaster occurrences is 2.826531 .

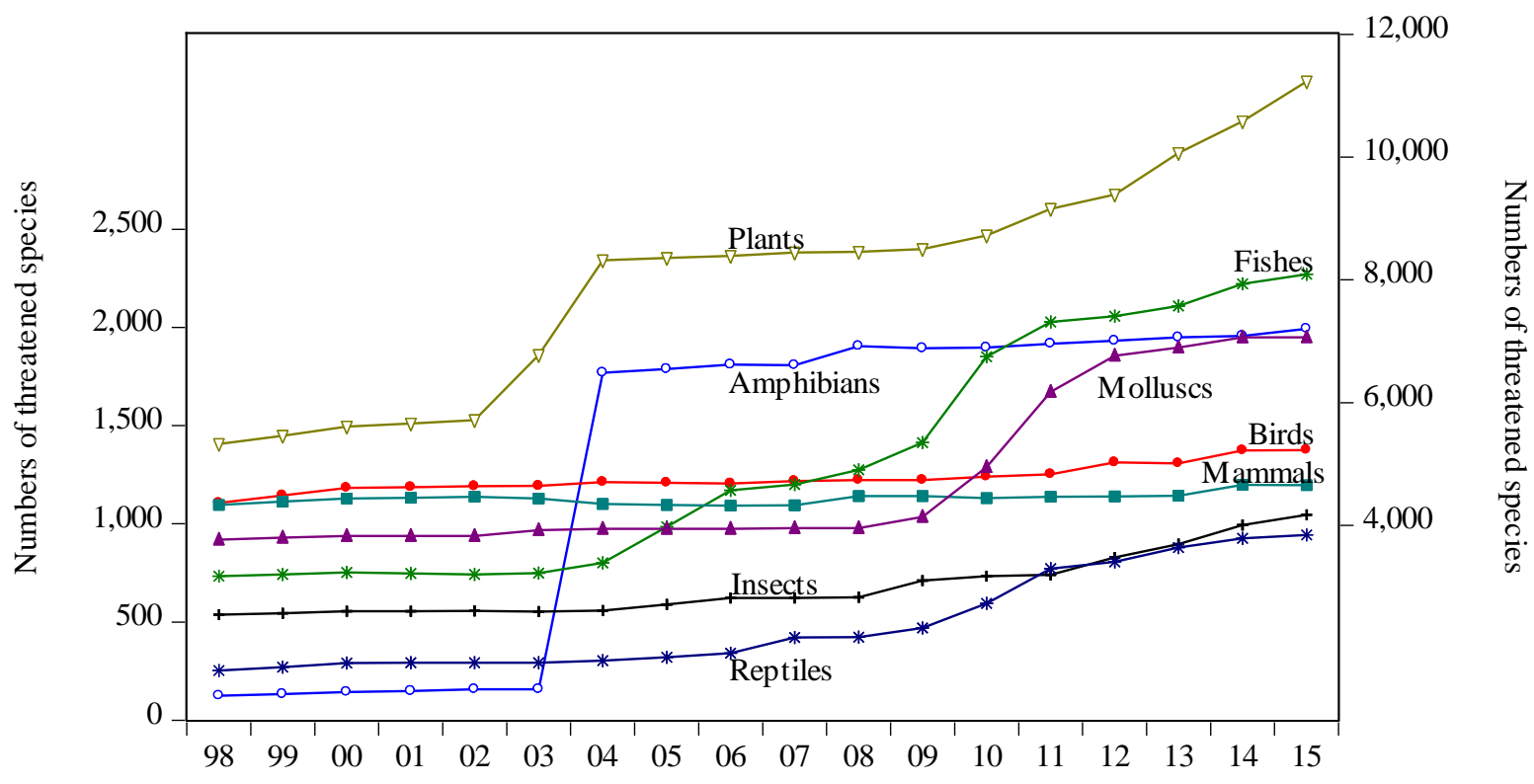

Figure 1: Trends in the Number of Threatened Species, 1998 - 2015 
- Number of Natural Dis as ter Occurrences

- Temperature

- Precipitation

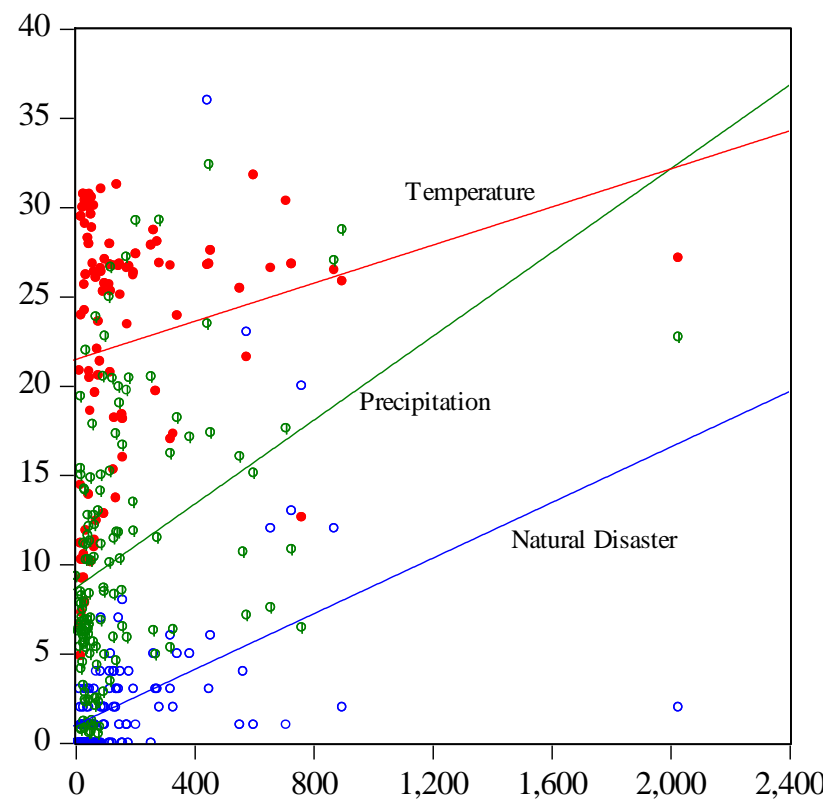

Total Number of Threatened Species

Figure 2: Correlation between Threatened Species and Climate Change Indicators

- Birds

- Fishes

- Mammals

* Plants

$\times$ Reptiles

+ Total species

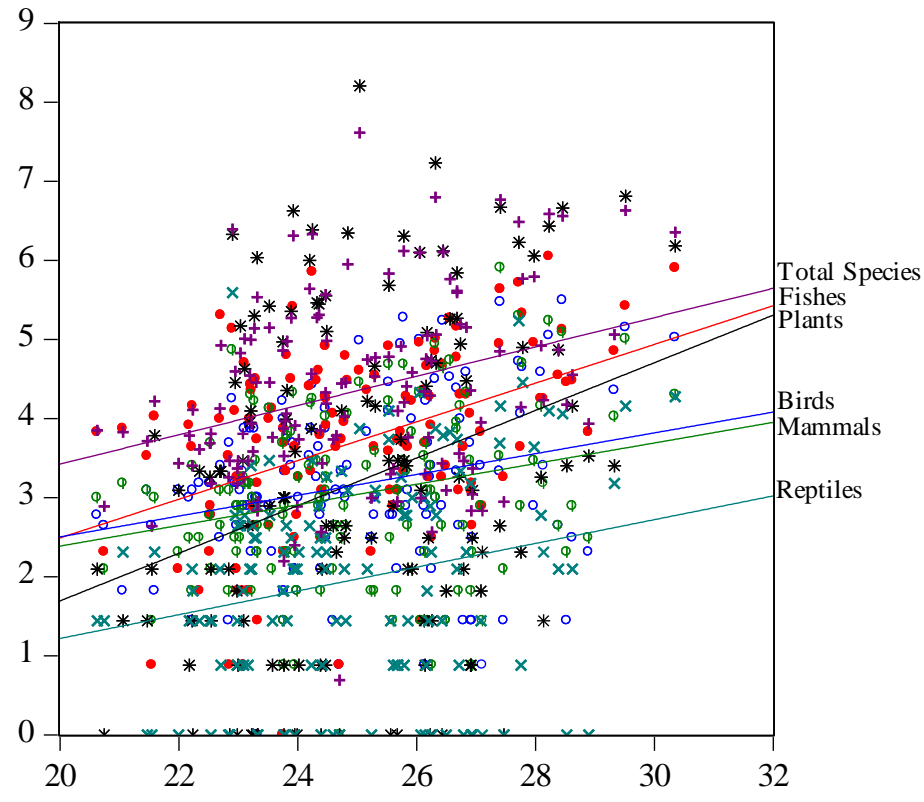

Real GDP

Figure 3: Correlation between Log Real GDP and Log Number of Threatened Species 